\title{
胃・扁桃へ転移を認めた肺癌の一例
}

\section{A Case of Lung Cancer with Metastases to the Stomach \& the Tonsil}

\author{
小林 卓 $\cdot$ 石下泰堂 $\cdot$ 片山鏡男 $\cdot$ 永田康夫 $\cdot$ 三輪正夫 ·伊藤 元 $^{*}$ \\ 酒井秀造 ${ }^{* *}$. 中村宏雄
}

\begin{abstract}
抄録：65才女性の心窩部痛, 嘔吐, 食欲不振等の消化器症状を主訴とし, 右肺上葉 $\left(\mathrm{S}_{1}\right)$ に発生 して胃，扁桃，脳等へ転移をした肺癌の一例を報告する。臨床症状としては，上記の他， 嬹下障害及び左上下肢の不全麻痺, 表在覚低下, 構語障害を呈した。組織学的には, 大 型の細胞を主体とするも多形性の強い, 又多核巨細胞を多数認め, 且つCannivalism(共 喰現象)を伴う未分化大細胞癌の一亜型である巨細胞癌であった。尚, Alcian-Blue PAS 染色も陽性であった。
\end{abstract}

\section{はじめに}

肺癌の胃転移は, 比較的珍らしく原発性肺癌 の 1 〜 $\%$ とされている. また扁桃への肺癌の 転移は，極めて稀で報告が少ない。今回我々は 65才女性の胃,・扁桃，脳等へ転移した一例を経 験したので報告する。

症 例：65才, 女, 無職

主 訴：心窩部痛, 嘔気及び嘔吐

家族歴：特記する事なし。

既往歴：右沪胞性甲状腺腫にて55才の時手術. 現病歴：昭和 51 年 8 月より胃痛, 悪心, 嘔吐が 徐々に増強し，10月下旬には殆ど食物がとれな くなった為，51年11月 5 日精查及び治療を目的 として名古屋第一赤十字病院へ入院. 入院時, 左上肢の表在覚の低下と不全麻痺及び右扁桃腫 瘍を認めた。

人院時現症：体格小，意識正常，皮膚乾燥及 U゙貧血, 脈拍 $84 /$ 分, 不整, 体温 $36^{\circ} \mathrm{C}$, 血圧 $100 / 66$, リンパ節腫脹なし、眼瞼結膜蒼白, 球結膜黄疸

名古屋第一赤十字病院・内科

* 愛知医科大学 - 第一病理

**名古屋大学・医学部第一内科
なし、瞳孔正円，左右不同なし，対光反射正. 右扁桃に母指頭大の腫瘤を認む。心音清，肺は 聴打診上異常を認めず。腹部は心窝部に圧痛あ り，硬い癒着性の腫瘤を約 3 横指触知。溙蓋腱 反射及びアキレス腱反射は共に左で減弱，病的 反射はなし、又左上肢の表在覚の低下と不全麻 痺を認めた。

入院時一般検査所見：Table. 1 に示すように, 白血球増多, 血沈の促進, CRP $6+$ 等の炎症所 見と喀痰細胞診で未分化大細胞性癌細胞が検出 された。

胸部X線所見：Fig. 1 に示すように入院時の 胸部 $X$ 線で右肺尖 $\left(\mathrm{S}_{1}\right)$ に直径約 $5 \mathrm{~cm}$ の腫瘤影を, 又断層写真では背側より $7 \mathrm{~cm}$ を中心空洞を伴 う腫瘤影を認めた。

上部消化管 X 線検査：胃穹窒部と胃体上部を 中心に陰影欠損を認め(Fig. 2), 胃カメラにて隆 起型の腫瘤を認めた。又この部位からの生検に より，未分化大細胞癌の診断を得た。

臨床経過 (Fig. 3)：入院後, 発熱は消褪した が食欲不振, 全身衰弱は進行し, 左上肢の弛緩 性不全麻痺及び左上肢橈側表在覚の低下を認め, 
Table 1. Laboratory Data on admission (G.T. 65 y.o.)

\begin{tabular}{|c|c|}
\hline \multicolumn{2}{|c|}{ Peripheral blood } \\
\hline $\mathrm{RBC}$ & $382 \times 10^{4} / \mathrm{mm}^{3}$ \\
\hline WBC & $237 \times 10^{2} / \mathrm{mm}^{3}$ \\
\hline $\mathrm{Hb}$ & $12.2 \mathrm{~g} / \mathrm{dl}$ \\
\hline Platelet & $30 \times 10^{4} / \mathrm{mm}^{3}$ \\
\hline \multicolumn{2}{|c|}{$\operatorname{ESR}\left(1^{\circ}\right) 84 \mathrm{~mm}$} \\
\hline \multirow[t]{5}{*}{ Urinalysis } & Protein $(-)$ \\
\hline & Sugar (+) \\
\hline & Urobilinogen $(\mathrm{N})$ \\
\hline & Sediment RBC $3-5 / 1$ \\
\hline & WBC $1 / 5-6$ \\
\hline Feces & Occult bleeding $(+)$ \\
\hline \multirow{2}{*}{\multicolumn{2}{|c|}{$\begin{array}{l}\text { Serological Exam. CRP } 6+\text {, RA (-) } \\
\text { ASLO } 125 \text { Todd } \downarrow \text {, STS }(-)\end{array}$}} \\
\hline & \\
\hline FBS & $104 \mathrm{mg} / \mathrm{dl}$ \\
\hline \multicolumn{2}{|c|}{ Exam of Sputum. T.B. $(-)$} \\
\hline \multicolumn{2}{|c|}{ Large cell cancer cell $(+)$} \\
\hline Manteux-R & $3 \times 5(-)$ \\
\hline ECG & Sinus tachycardia \\
\hline
\end{tabular}

$\begin{array}{ll}\text { Blood Chemistry } \\ \text { GOT } & 15 \mathrm{mU} / \mathrm{ml} \\ \text { GPT } & 26 \mathrm{mU} / \mathrm{ml} \\ \text { Al-P } & 123 \mathrm{mU} / \mathrm{ml} \\ \text { T. Bil. } & 0.3 \mathrm{mg} / \mathrm{dl} \\ \text { T.P. } & 6.2 \mathrm{~g} / \mathrm{dl} \\ \text { A/G } & 0.77 \\ \text { Alb. } & 41.1 \% \\ \alpha_{1}-\text { Glob. } & 9.0 \% \\ \alpha_{2} \text {-Glob. } & 16.1 \% \\ \beta \text {-Glob. } & 10.1 \% \\ \gamma \text {-Glob. } & 23.5 \% \\ \text { Na } & 136 \mathrm{mEq} / \mathrm{ml} \\ \text { K } & 4.9 \mathrm{mEq} / \mathrm{ml} \\ \text { Cl } . & 97 \mathrm{mEq} / \mathrm{ml} \\ \text { T. Chol. } & 178 \mathrm{mg} / \mathrm{dl} \\ \text { BUN } & 14 \mathrm{mg} / \mathrm{dl} \\ \text { LDH } & 136 \mathrm{units} \\ \text { Craniogram } & \text { normal } \\ \text { Spinogram } & \text { normal }\end{array}$

Fig.1 入院時胸部 X 線像

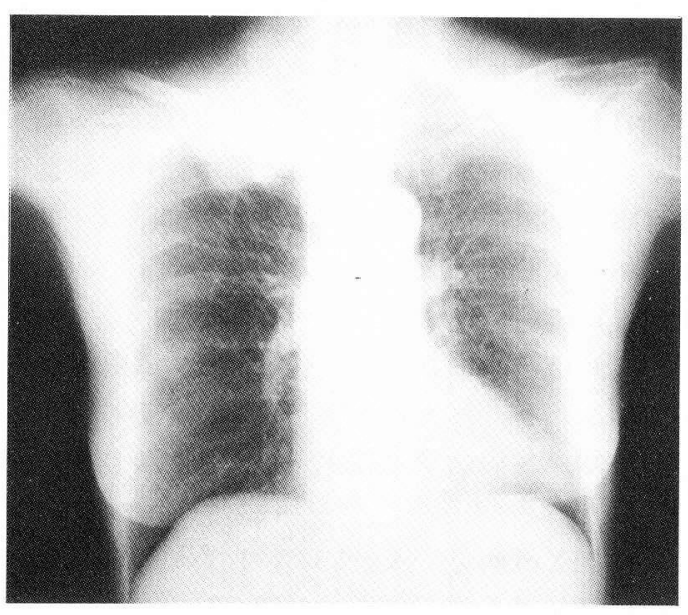

次いで構語障害, 左下肢の不全麻盘が出現し徐 徐に悪化した。これらの症状及び脳シンチグラ ムより右運動領野附近のSpace taking lesion が 考えられた。

第44病院日よりは意識混浊し，下顎呼吸とな り血圧下降して, 第47病院日に悪液質にて死亡 した。

剖検所見：肺は右上葉 $\left(S_{1}\right)$ に手挙大 $(5 \times 8 \mathrm{~cm})$ で周囲と凂着し, 割面が黄白色の壊死性の強い
Fig.2 入院時上部消化管 $\mathrm{X}$ 線像

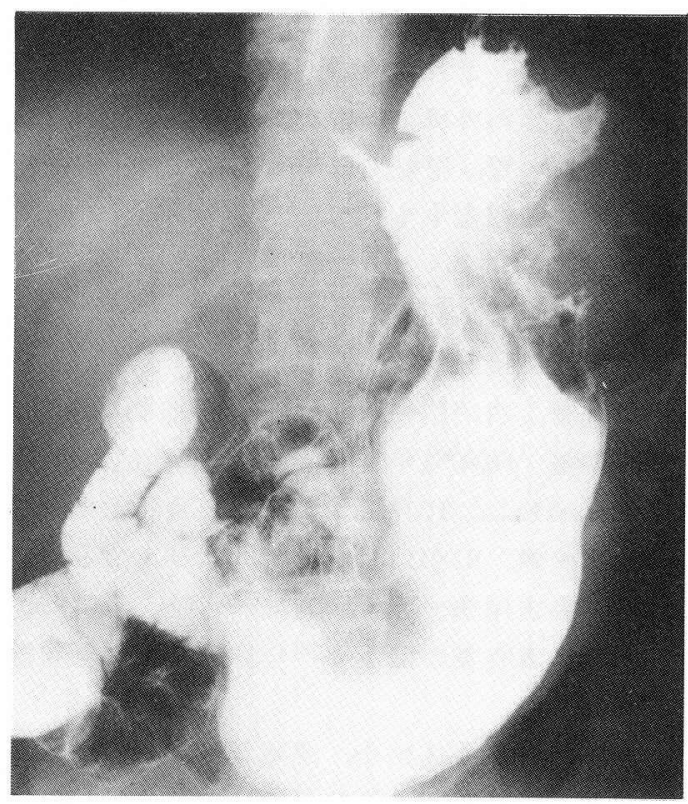

癌腫を認女(Fig. 4), 胃は胃壁大弯側穹蕯部を 中心に肝, 膵, 脾と接する腫瘍を認めた (Fig.5)。 又転移としては, 右扁桃, 喉頭蓋, 脾, 膵, 左 甲状腺, 右大脳半球, 両側副腎, 及び肺門リン パ節と大動脈周囲リンパ節に認めた。 
Fig.3 経過表

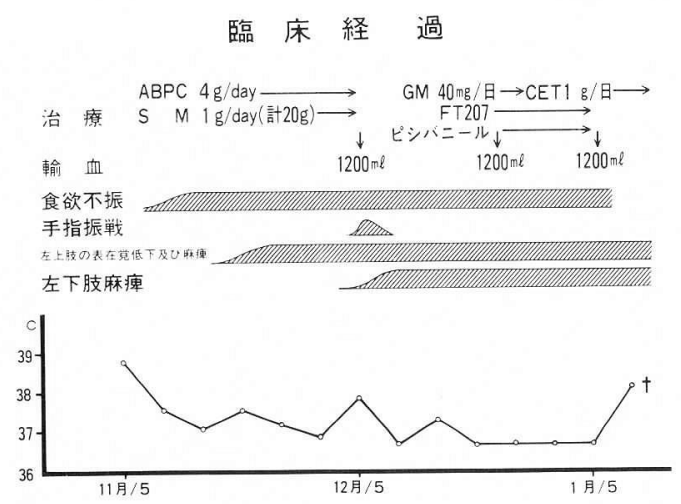

Fig.4 右肺。矢印の部(上葉 $\left.\mathrm{S}_{1}\right)$ に癌腫を認㤩。

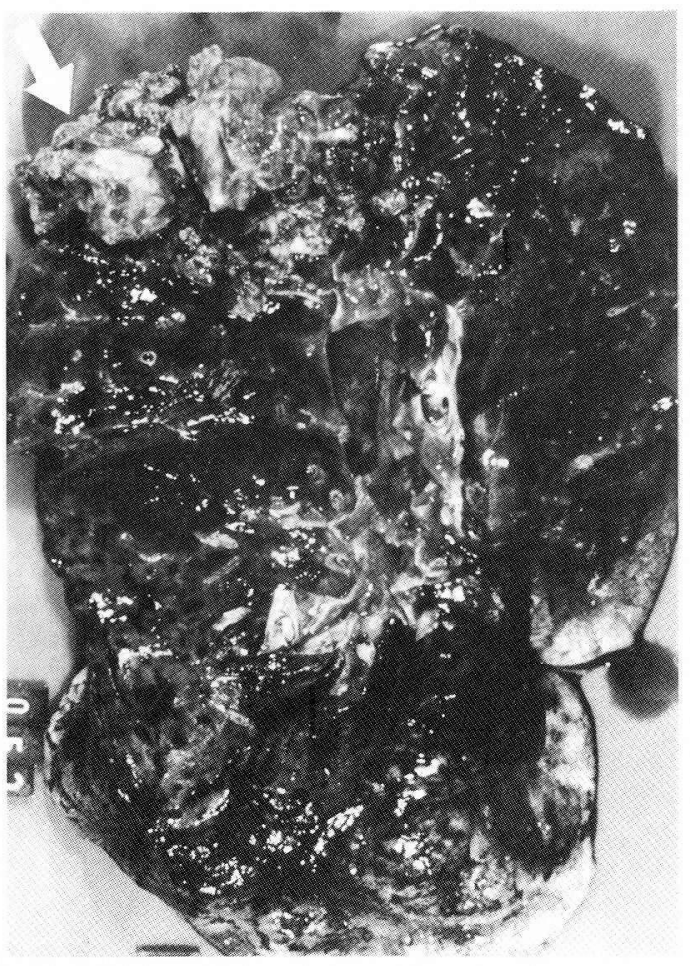

病理組織学的には, 肺は壊死傾向が強いが大 型の癌細胞を主体とし，巨細胞がかなり多数認 められ(Fig. 6), Cannivalismを伴う多形性の強 いもので(Fig. 7)これらの組織学的特長は, 胃 (Fig. 8) 扁桃(Fig. 9) 脳で共通しており，Alcian-Blue PAS染色陽性(Fig.10) で, 肺原発の大 細胞癌の一亜型である巨細胞癌と診断した。
Fig.5 胃。矢印の部に壊死を伴う䙖腫を認めた。

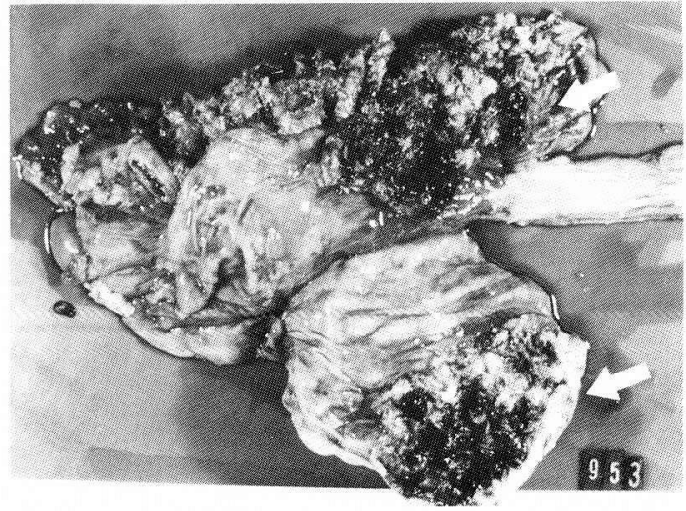

Fig.6 右肺腫漡. 多数の巨細胞老伴う多形性の強 い大細胞癌。X300.

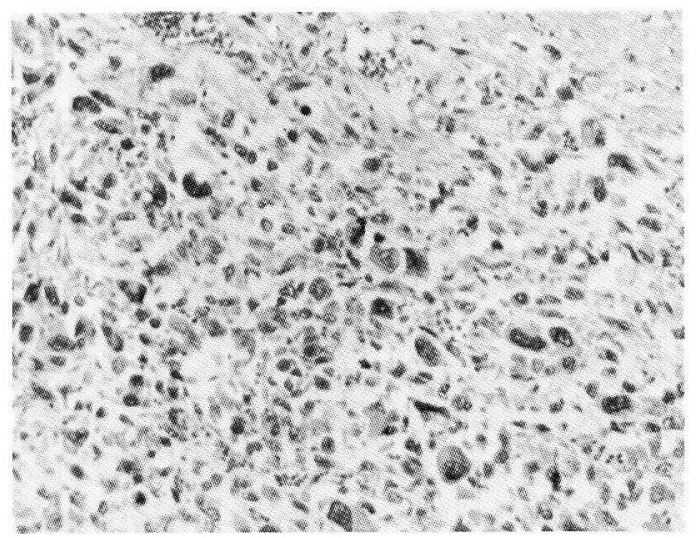

Fig.7 Cannivalismがみられる。(胃)。600X。

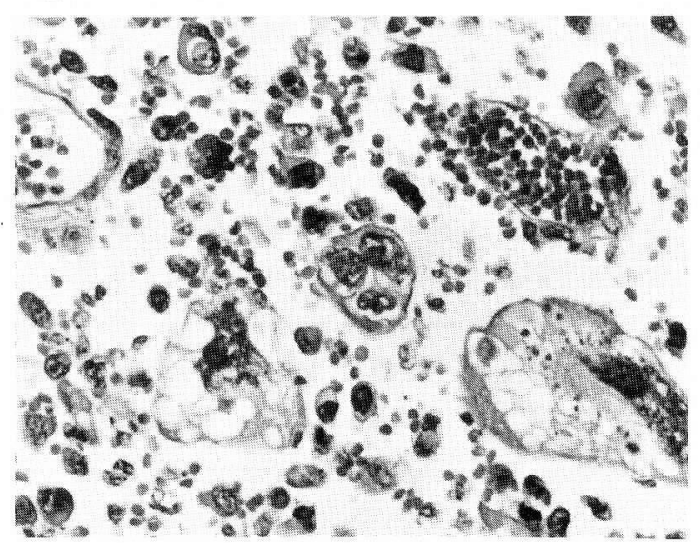

考 按：肺癌の胃転移は比較的稀で, 末外ら ${ }^{1)}$ は, 原発性肺癌の剖検例150例中 2 例 (1.4\%), 寺島 ${ }^{2)}$ は, 同じく剖検例113例中の 3 例 (2.7\%) 
Fig.8 胃(転移)。所々に巨細胞を見る。X 300 .

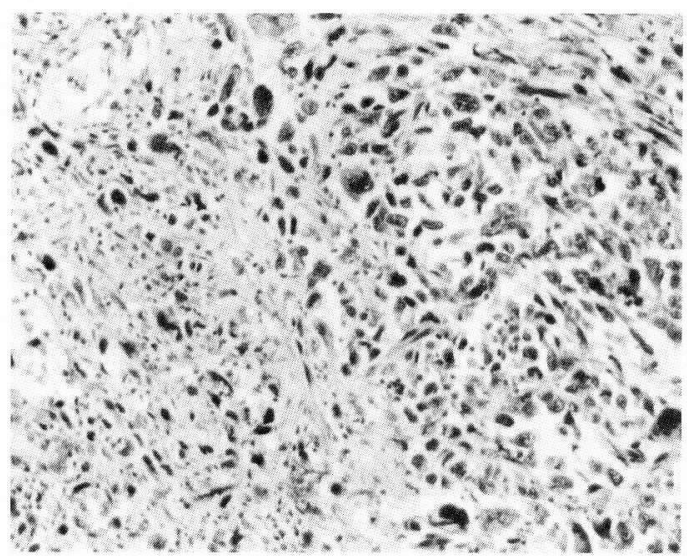

又, 妹尾 ${ }^{3)}$ の文献的考察によれば本邦原発性肺癌 336例中4.8\%に胃転移を認めている. 又, Ochsner ${ }^{4}$ によると 3,047 例中 $4.3 \%$ とし，いずれも $5 \%$ 以 下である。

胃転移の部位については，胃底部小弯側に多 いといわれる が，本例のような大弯側への転 移もみられている。本症例では胃カメラにて転 移性腫瘍を思わせる粘膜下から隆起する腫瘤を 認め，血行性遠隔転移を思わせた。

胃転移と組織型の関係は，特に明らかでなく3， 腺癌と脳, 肝, 肺, 腎, 脾転移, 或いは扁平上 皮癌と骨転移，未分化小細胞癌と膵転移といっ た相関は知られていない。本例は，未分化大細 胞癌の覀型で悪性度の高い巨細胞癌であり，そ れ故に，胃，扁桃を含志広忛な転移をきたした ものと思われる。

次に, 扁桃転移であるが, 従来原発性肺癌を 含め悪性腫瘍の扁桃への転移は極めて稀である。 海老原 ${ }^{6)}$ によれば，口蓋扁桃に原発する悪性腫 瘍113例中67例が悪性リンパ腫であり，45例が扁 平上皮癌としているが，続発性扁桃腫瘍にはふ れていない。又 Tapley $^{7)}$ らは, 原発性扁桃腫 瘍88例中 2 例に続発性口腔癌を報告している が, 他藏器からの転移の記載はない。一方, 口盖扁桃を含む原発性中咽頭癌の肺入の転移に ついては10例中 3 例, 消化管への転移について は10例中 1 例の報告がある。․․ 本例は，肺癌の胃， 扁桃等に転移した例で，極めて稀なものと思わ
Fig.9 右扁桃(転移)。粘膜下に大型の細胞の増牛 を見る。 X300。

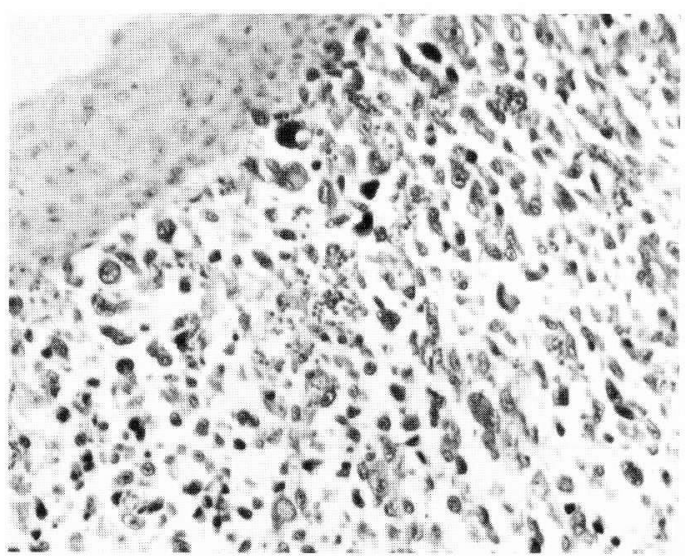

Fig.10 肺。視野の中央の濃淡を示す細胞の淡いと ころが青く濃い部分が赤染している。 (Alcian-Blue PAS染色.600X.)

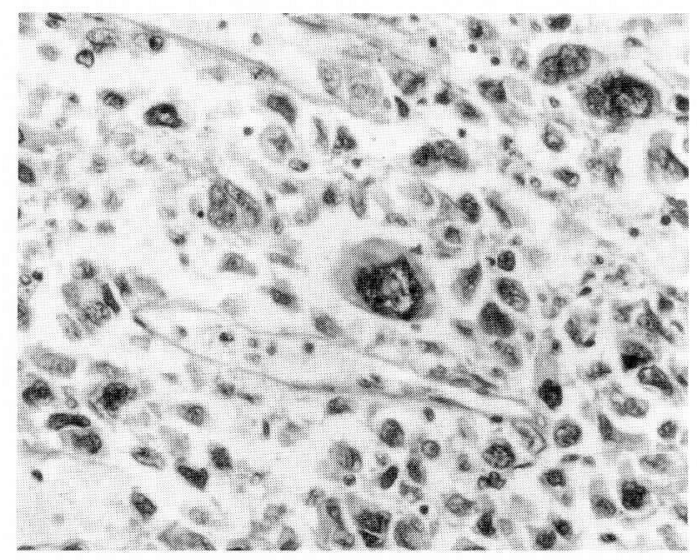

れる゙.

まとめ：65才女性の胃，扁桃等に転移をきた した肺癌の一例を報告した。組織学的には，末 分化大細胞癌の一亜型である巨細胞癌であった。

尚，本論文の要旨は，第30回日本肺癌学会中 部支部会 $(1977 \cdot 5 \cdot 28$ 。名古屋)において報告し た。 
1）末舛恵一：医学のあゆみ, $62: 817,1967$.

2）寺島文雄：慶応医学, 36：1171, 1959.

3) Senoo T. : Medical Journal of Osaka University, 7:515, 1956.

4) Ochsner, H. et al. : Amer. Rev. Tuber. $70: 763$, 1954.
5）山際裕史他：総合臨床，25：1396，1976.

6）海老原敏他：頭頸部腫瘍図譜(中山書店), p218, 1975.

7) Tapley, N.V et al. : Amer. J. Roent. \& Radium Therapy \& Nuclear Medicine, 82:626, 1959.

（原稿受付 1977 年10月11日）

\title{
A Case of Lung Cancer with Metastases to the Stomach \& the Tonsil
}

\author{
Kobayashi,T.M.D., Ishioroshi,T.M.D., Katayama,A.M.D., \\ Nagata,Y.M.D., Miwa,M.M.D., Nakamura,H.M.D., \\ Itoh,G.M.D. *, Sakai.S.M.D.** \\ Internal Medicine, Nagoya First Red Cross Hospital, Nagoya. \\ *First Dept. of Pathology, Aichi medical College, Aichi. \\ **First Dept. of Internal Medicine, Nagoya University, School of \\ Medicine, Nagoya.
}

A 65 -year-old woman with chief complaints of anorexia, nausea and epigastralgia was diagnosed as primary lung cancer. She was suffered from dysphagia, dysarthria, hypesthesia of superficial sensation of left limb, left-hemiparesis and cough after admission. The cancer originated from the right upper lobe $\left(S_{1}\right)$ of lung metastasized to the stomach, the right tonsil, the epiglottis, the spleen, the pancreas, the right hemisphere of the brain, hilar lymph nodes, periaortic lymph nodes and the bilateral adrenals. Histological examination revealed that the cancer was undifferenciated large cell carcinoma including considerable number of giant cells, cannivalism and positive Alcian-Blue PAS stainning. 